\title{
TOURISM ACTIVITY AMONG SENIORS: A CASE-STUDY FROM WARMIAN AND MASURIAN VOIVODESHIP
}

\author{
JOANNA ZIELIŃSKA-SZCZEPKOWSKA, ${ }^{1}$ MAŁGORZATA SAMUSJEW ${ }^{2}$ \\ University of Warmia and Mazury in Olsztyn, Association of Polish Communes of Euroregion Baltic, POLAND \\ ${ }^{1}$ e-mail: joanna.zielinska@uwm.edu.pl \\ 2e-mail:malgorzatas@eurobalt.pl
}

\begin{abstract}
KEYWORDS | demographic changes, tourism activity, preferences and behaviours of senior tourists
\begin{tabular}{l|l} 
ABSTRACT & This work focuses on the issues related to tourist activity of older people. The paper presents the
\end{tabular} results of the pilot research conducted during the summer of 2013 on a sample of 141 people age 55 and older living in the Warmia and Mazury region. This study, carried out within the framework of the "TOURAGE project - Developing Senior Tourism in Remote Regions", revealed the average senior tourist from the Warmia and Mazury region and his or her holiday preferences. In the analysis, the main features of tourist activity was described, including frequency of tourism, motivations and forms of participation in tourism, organization of tourist activities, and how seniors spend free time. These considerations expanded to an analysis of the issues of tourism activity among seniors.
\end{abstract}

\section{Introduction}

The aging of populations observed in recent years is one of the most important social and economic dilemmas of the modern world. While in 2000 the percentage of women over the age of 60 and men over 65 was $14 \%$ of the population, according to the demographic forecasts, by 2030 this number is expected to rise to $24 \%$ and reach 9.29 million people on average across Europe. ${ }^{1}$

\footnotetext{
${ }^{1}$ Rocznik Demograficzny 2010, GUS, Warszawa 2010, p. 167.
} 
According to the data of Poland's Central Statistical Office, in the last quarter-century the country has observed a slowdown in demographic growth. The aging of the Polish population resulting in part from a lengthening of life expectancy is at the same time exacerbated by a low fertility rate. In addition, these changes are further intensified by increased emigration of young people. It is true that Poland is still perceived in Europe as a demographically young country; however, from the beginning of the 1990s the average age of a Polish citizen has increased by nearly seven years. In 2013, the average age for the entire Polish population was nearly 39, but higher for women (average of over 40) than men (average of 37). ${ }^{2}$

The data published by Eurostat shows that in Poland the number of people over 65 years old will increase from $13.5 \%$ in 2010 to $34.5 \%$ in 2060 . Despite a better starting position (a working age population that was almost four percentage points lower than the EU average), the process of the aging of the demographic structure in Poland will be much deeper than across the EU (in 2060, the population over 65 years old will be higher than the EU average by five percentage points). ${ }^{3}$ Therefore, in the near future Poland will have to deal with a demographically advanced population. ${ }^{4}$

The changing demographic structure of the population makes the subject of seniors' tourist activity of particular importance as a form of prevention of aging effects on the human body. ${ }^{5}$ The positive impact of physical activity on the health and wellbeing of older people is undeniable and confirmed by numerous studies. ${ }^{6}$ Participation in various forms of recreation has a significant impact on improving the health and quality of life of older people. Active tourism and leisure are special forms of recreation and refers to physical recreation, rather than passive forms of leisure, which research by $\mathrm{GUS}^{7}$ and $\mathrm{MSiT}^{8}$ shows is unfortunately the most favourite activities amongst Polish seniors. Physical activity in the form of hiking, walking, or cycling is closely related to the age of the respondents. Taking into account the results of research conducted by CSO in 2013, this

${ }^{2}$ Sytuacja demograficzna osób starszych i konsekwencje starzenia się ludności Polski w świetle prognozy na lata 2014-2050, GUS, Warszawa 2014, p. 2.

${ }^{3} \mathrm{http} / /$ epp.eurostat.ec.europa.eu/cache/ITY_PUBLIC/3-08062011-BP/EN/3-08062011-BP-EN.PDF (14.04.2013).

${ }^{4}$ See J. Zielińska-Szczepkowska, A. Źróbek Różańska, Aktywność władz samorządowych w obliczu zmian demograficznych kształtujacych sektor turystyczny, przykład województwa warmińsko-mazurskiego, Studia i Prace Wydziału Nauk Ekonomicznych i Zarządzania nr 37, Zeszyty Naukowe Uniwersytetu Szczecińskiego nr 826, Wydawnictwo Naukowe Uniwersytetu Szczecińskiego, Szczecin 2014.

${ }^{5}$ Z. Ossowski, T. Taraszkiewicz, M. Formella, Aktywność turystyczna seniorów szansą na rozwój turystyki w Polsce, Ekonomiczne problemy usług nr 82, Zeszyty Naukowe Uniwersytetu Szczecińskiego nr 697, Szczecin 2012, p. 295

${ }^{6}$ See H. Szwarc, T. Wolańska, T. Łobożewicz, Rekreacja i turystyka ludzi w starszym wieku. Instytut Wydawniczy Związków Zawodowych, Warszawa 1988; A. Grzanka-Tykwińska, K. Kędziora-Kornatowska, Znaczenie wybranych form aktywności $w$ życiu osób w podeszłym wieku, „Gerontologia Polska” 2010, t. 18, nr 1, Kraków 2010, pp. 29-32; K. Zamłyńska, Turystyka i rekreacja a promocja zdrowia rodziny, Roczniki Naukowe AWF w Poznaniu nr 54, Poznań 2005, pp. 173-180.

${ }^{7}$ GUS - Central Statistic Office in Poland, Turystyka $i$ wypoczynek w gospodarstwach domowych w 2013 r., GUS, Warszawa 2014, p. 77. The research was conducted in 2013 on a group of 4,548 households in Poland, among them 1,308 households were represented by a retired person.

${ }^{8}$ MSiT - Ministry of Sport and Tourism in Poland, Preferencje osób starszych dotyczące wyjazdów turystycznych, Korporacja Badawcza Pretendent, Wrocław 2011, p. 8. In 2010 the research was conducted in Poland on a group of 1,067 people aged over 55 years and more. 
form of activity constituted only $9 \%$ of the oldest group of respondents (aged 65 years and older), while the most common forms of leisure activities chosen by Polish seniors were: listening to the radio and music, watching TV and videos, and use of the internet ( $26 \%$ of respondents), reading $(13 \%)$ and passive recreation $(12 \%)$. Only $7 \%$ of respondents in this age group spend their time actively on a garden plot.

Although tourism is considered to be one of the most attractive forms of recreation, it is still not a very popular form of activity for elderly people in Poland. ${ }^{9}$ Research conducted in 2010 and commissioned by MSiT, shows that as many as $67 \%$ of Polish seniors (age 55 years and older) did not travel anywhere, while $15 \%$ went on long-term trips, $10 \%$ cited touristic reasons, and $8 \%$ went on short-term trips inside the country. ${ }^{10}$

The reason for the low interest in tourist trips by seniors in Poland may stem from economic reasons ${ }^{11}$, but there is also a lack of special offers targeted to this specific group. This is confirmed by numerous meetings with seniors and representatives of local authorities, organizations working for seniors, University of the Third Age, and tourism companies, which took place in 2013 in the Warmia and Mazury regiohn. Among the major issues that have a negative influence on the size of the senior tourism market in Poland, participants in these workshops listed, among others:

- difficulties with passing along tourism offers to seniors because of the low internet usage rate by this specific group, which is now one of the most important sales channels,

- the lack of publications on tourist packages for seniors, which results in a lack of interest among local tour operators to promote special offers for the elderly,

- lack of funds for the implementation of local projects that support the development of senior tourism. ${ }^{12}$

The purpose of this article is to provide a basis for the preliminary analysis of tourist activity of the residents of the Warmian and Masurian Voivodeship over 55 years of age. Pilot studies have been carried out on a group of 141 people from the region of the Warmia and Masurian Voivodeship during the summer of 2013. In the article, beyond the results of a survey that has been carried out, the Polish and foreign literature as well as the statistical data published by GUS and Eurostat, have been used. We also use the strategic document published on the website of the European Commission as well as the information from the completed TOURAGE project which encouraged the development of international senior tourism.

${ }^{9}$ See J. Śniadek, A. Zajadacz, Senior Citizens and Their Leisure Activity: Understanding Leisure Behaviour of Elderly People in Poland, "Studies in Physical Culture and Tourism" 2010, Vol. 17, No. 2, pp. $193-204$.

${ }^{10}$ Preferencje osób starszych..., p. 16.

${ }^{11}$ More information about economic factors influence on preferences of senior tourists in Poland in: J. Śniadek, Konsumpcja turystyczna polskich seniorów na tle globalnych tendencji w turystyce, " Gerontologia Polska" 2007, t. 15, nr 1-2, pp. 21-30.

12 These are the conclusions of the seminar entitled „Seniors in tourism - a desirable target group or unwanted customers?"which took place on 21st March 2013 in Elbląg. The seminar was organized by the Association of Polish Communes Euroregion Baltic within the TOURAGE project. There were representatives of local authorities, senior citizens associations, academia and tourism industry. The discussion was moderated by Ms Joanna Zielińska-Szczepkowska from the University of Warmia and Mazury in Olsztyn, www.tourage.eu/index.php?mact=News,cntnt01,detail,0\&cntnt01articl eid $=44 \&$ cntnt01origid $=66 \&$ cntnt01 returnid $=66$. 


\section{TOURAGE Project - Developing Senior Tourism in Remote Regions as a case-study of the development of tourism possibilities for the growing segment of eldeply travellers}

The profound demographic changes taking place in recent years in Europe have been not only the subject of scientific analysis but also strategic plans undertaken at both the national and regional levels as well as by the EU institutions themselves. In 2010, the European Commission, in its document Europe - the Most Popular Tourist Destination in the World - a New Political Framework for Tourism in Europe, pointed out that beyond such challenges as the economic crisis, climate change or the development of new technologies, the European tourism sector should take into consideration issues that stem from an aging society..$^{13}$

These changes will need a quick response from the tourism sector to maintain its present level of competitiveness. According to the demographic prognosis for 2020, seniors will constitute $20 \%$ of the population and also have both purchasing power and leisure time. To fully exploit the economic potential of the silver economy, it is necessary to identify seniors' needs and to create a suitable offer for them as tourists.

The answer to these challenges was the "TOURAGE project - Developing Senior Tourism in Remote Regions" which ran from 2012 to 2014 and was founded by the Interregional Cooperation Programme (INTERREG IVC). ${ }^{14}$ The project grew out of the idea that instead of challenges, demographic change can also bring opportunities to regions. Tourism is one of the fastest-growing industries in Europe, and relatively remote regions have much unexploited and yet widely unknown development potential in this sector. The project seeks to find best practices for developing tourism among the growing segment of elderly travellers.

The overall objective of the project is to enhance the regional economy by means of senior tourism development and to support active and healthy aging. The project aims to enlighten responsible personnel among regional authorities, decision-makers and politicians in the field, with the challenges and benefits, future possibilities and trends, and above all, best practices exchanged and deployed. In the realization of this project there were involved 12 partners from 10 EU countries:

- Regional Council of North Karelia, Finland (Lead Partner),

- Bourgas Regional Tourist Association, Bulgaria,

- Region of East Macedonia \& Thrace, Greece,

- Lake Balaton Development Coordination Agency, Hungary,

- Szabolcs-Szatmár-Bereg County Regional Development and Environmental Management Agency, Hungary,

- West Regional Authority, Ireland,

- Vidzeme Planning Region, Latvia,

- Association of Polish Communes of Euroregion Baltic, Poland,

${ }^{13}$ Europa - najpopularniejszy kierunek turystyczny na świecie - nowe ramy polityczne dla europejskiego sektora turystycznego, KOM (2010) 352, Bruksela 2010.

${ }^{14}$ www.tourage.eu (19.01.2015). 
- Podkarpacie Region, Poland,

- North-West Regional Development Agency, Romania (Project partner till 31.12.2012),

- County Council of Granada, Spain,

- Regional Development Agency of the Prešov Self-Governing Region, Slovakia.

The main activities carried out under the project include:

a) indentification and exchange of good practices which help take over the challenges associated with senior tourism ("silver tourism");

b) evaluation of the most important challenges of silver tourism in the regions;

c) exchange experiences on senior tourism through successful seminars, working groups and study visits;

d) developing of joint methodologies and giving policy recommendations based on good practices exchanged during the project;

e) increasing networking capacity and synergies within European-wide silver economy networks and projects;

f) finding of solution to turn population ageing also into asset and overcome structural change by new innovative means;

g) promote sustainable regional economy and wellbeing.

The results gained in this collaboration will be essential instrument to communicate to the rest of Europe the means by which "The Senior Tourism Model" can be created and enhanced and also what kind of tools can be used to improve Regional Senior Tourism Policies.

\section{Material and Methods}

The aim of the research is to identify the senior tourism activity, how seniors spend their free time as well as identify some selected factors motivating elderly people to lead active lives. The empirical material that forms the basis of this work was collected during surveys conducted in the period June-August 2013. The main criterion for the selection of the sample has been the respondent's age (at least 55) and place of residence (Warmian and Masurian Voivodeship). The study has collected 141 completed questionnaires that are correctly filled in. The study is carried out on the group composed of $17 \%$ men and $83 \%$ women. All of the respondents are retired, and, at the period in question, most of them were retired for more than six years $(6-15$ years, $53 \%$ of respondents; more than 15 years, $6 \%$ ).

The adopted research method is a diagnostic survey in the form of a questionnaire. The questionnaire consisted of 14 items, including open (2), mixed (6) and closed (6) questions with either single or limited multiple choices, and a section on gender, age, education, labour history and material wellbeing. The vast majority of the questions are related to the determination of preferences and needs of seniors in the field of tourism. The scope of the questions include: the preferred duration of the holiday, destination (in the country or abroad), preferred time of year (seasons), organization of leisure, sources of information about tours, means of transport, company kept during the holiday, factors that influenced the decision to travel, reasons to take the decision 
to leave for a holiday, and reasons that encouraged them to choose particular destinations. The data analysis involves descriptive statistical methods.

\section{Results}

In reference to the research by J. Śniadek (2007), observations of the tourist market in Europe show a tendency to greater interest in tourism among seniors from Western Europe than from Poland. In the opinion of the tourism industry, the ordinary retired Polish tourist has relatively little purchasing power because of the low living standard in retirement. ${ }^{15}$

The survey conducted among seniors from the Warmian and Masurian Voivodeship shows a completely different result. It is true that $27 \%$ of respondents have identified their financial status as unsatisfactory; however, the vast majority of respondents identified their monthly income as on the level of the average monthly pension ${ }^{16}(28 \%)$ and above average (43\%). That question is related to another one about the continued employment after retirement. Among the entire group of respondents, $17 \%$ have declared some form of employment. This is an important message from the answers - that seniors are open to entrepreneurship. A correlation of these two questions indicates that active tourists are primarily those seniors who have additional financial resources beyond their retirement incomes.

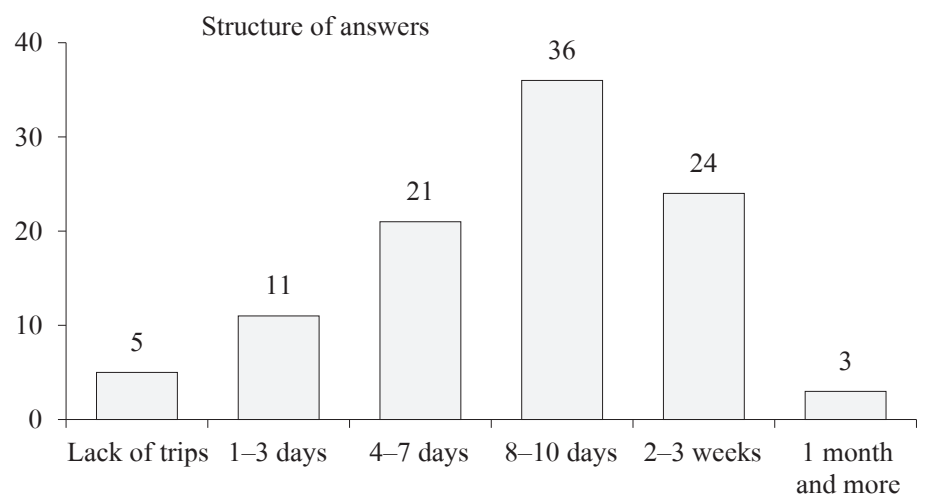

Figure 1. Usual length of holiday since retirement pension (\%)

Source: own study based on the survey.

One of the questions included in the questionnaire related to the usual length of a senior's holiday since they have been living on their retirement pension. Most of the respondents prefer to take $8-10$ day holidays (37\%) or even shorter stays similar to working periods (4-7 days, 21\%)

15 J. Śniadek, Konsumpcja turystyczna polskich seniorów..., p. 21.

${ }^{16}$ In 2013 average gross monthly pension from the Social Insurance Institution in Poland was 1,970.39 PLN, Emerytury i renty w 2013 r., GUS, Warszawa 2014, p. 65. 
(Figure 1). Some of them answer with longer stays (2-3 weeks, 24\%; 1 month or more, only 3\%). The hypothesis that seniors are willing to spend more time on holiday is not true, as their travel patterns are quite similar to other active citizens, with only some group of seniors spending more time on holiday, usually at nursing homes.

Our results show that the seniors in the survey prefer domestic trips (71\%). However, almost a quarter of the respondents prefer to travel abroad during their holidays. This shows that seniors are an important potential market. Regional strategies should focus on how to reach internationally oriented senior tourists and on how to attract them to the respective regions. These seniors are open to travel abroad during their retirement as well, though it is more a question of whether service providers can understand their specific needs. The latter part of the questionnaire tries to answer these questions as well and determine the specific motivations and needs of these tourists.

Analysing the respondents in terms of in which season seniors are willing to travel, the results show they prefer to travel in summer (37\%), though for this age group travelling in spring (27\%) and autumn (31\%) are also an acceptable periods (Figure 2). Winter is the least preferred season for holidays, mostly because of the safety aspect of the specific weather conditions. Bearing in mind the European Union policy on dealing with the problem of seasonality in tourism, it seems reasonable that the tourism sector in Poland should see an opportunity in the creation of individual tourist offers that are cheaper for seniors in low season. A very good example of such activities is found in Spain within the Europe Senior Tourism Programme. ${ }^{17}$ It is worth noting its social benefits: from October 2010 to April 2011, a total of 54,713 people from 16 European countries used the programme. The economic aspect of this was significant: the programme generated EUR 35 million and 880 new jobs. ${ }^{18}$

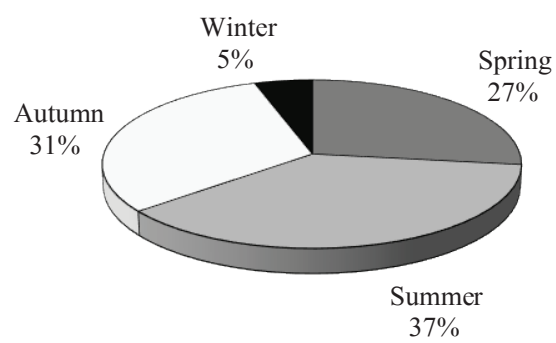

Figure 2. Season of senior tourism

Source: own study based on the survey.

${ }^{17}$ Europe Senior Tourism is a pioneering project worldwide. It is a travel programme promoted by the Spanish government, designed for European seniors over 55 who wish to enjoy active holidays while sharing experiences, www. europeseniortourism.eu/pl/index.html (20.02.2015).

${ }^{18}$ Evaluation of the profitability and economic impact generated by the Europe Senior Tourism Programme. Executive summary, Innova Management, Turismo-Ocio-Hotelaría, August 2011, www.europeseniortourism.eu/export/ sites/senior/comun/descargas/evaluationEuropeSeniorTourismProgramme.pdf (27.02.2015). 
Most of the seniors surveyed prefer to organise their travel individually (30\%) or by purchasing travel/accommodations through a travel agency $(32 \%)$. There is one important note about the role of various pensioner organisations and associations, and also some social tourism schemes have been mentioned by respondents. The pensioner organisations (such as pensioners' clubs, thematic pensioner associations, University of the Third Age) are key players in organising group travel for seniors. Also, some associations (tourism, religious) coordinate travel for seniors (although they are not specifically focused on seniors in their offers). Package tours/all inclusive holidays booked via the internet were bought by only $2 \%$ of the surveyed seniors.

The seniors report personal experience (47\%), family (28\%) and friends (62\%) are the most important sources of information for making decisions on travels. Regular media and social media are not relevant sources of information (for only $7 \%$ of respondents), although according to the results of national research, internet users over 50 years of age in Poland are relatively active on social networking sites, amounting to almost $70 \%$ of those age $50-64$, and $50 \%$ of those 65 or older. ${ }^{19}$ In the category of "other", some specific sources of information are mentioned: while pensioner organisations (clubs, University of the Third Age) are crucial, suggestions from doctors have been mentioned as well.

A spouse/partner (41\%) and friends (38\%) are the most common travel mates based on the answers received (31\%). Every tenth respondent spent time alone (11\%), while only 5\% of the respondents decide to holiday with their grandchildren or other relatives.

Three questions especially focus on the motivations and needs of seniors. As this group is treated as a new, emerging market for tourism products, these specificities could be important to the development of new destinations and services especially designed for seniors.

Financial reasons (45\%) and health problems (54\%) are the main barriers of travel for seniors. Financial issues are specific to the periphery of the EU and especially in the low-income areas of Europe, which shows the importance of social tourism for seniors. A third group of barriers is the lack of transport connections, and safety at the destination and during travel. These are mostly related to the logistics of senior tourism, which are in line with the view that they prefer to travel in groups (not alone), are looking for a safe holiday where they can get all services they require at the necessary quality, and a destination that can be easily reached by direct transportation links.

The rest and silence is an extremely important factor for seniors (65\% of the answers altogether) when they plan their holidays (Table 1). It is an important criterion for the Warmian and Masurian region's plan to extend senior tourism. It should offer places that are relaxing and which provide a safe environment for seniors. Family is also a major motivation factor for holidays (52\%). In many cases family members (children, grandchildren) are living farther away and holidays are a way to meet with family members. For seniors, it is also important to escape daily routines $(39 \%$, similar to younger people), experience something new (47\%), make new friends, and to socialize (43\%).

19 B. Szmigielska, A. Bąk, M. Hołda, Seniorzy jako użytkownicy internetu, "Nauka" 2012, nr 2, p. 145. 
Table 1. Motivations for holidays (\%)

\begin{tabular}{lrrrrrr}
\hline \multirow{2}{*}{ Reason for travelling } & \multicolumn{7}{c}{ Validity of the reason $^{*}$} \\
\cline { 2 - 7 } & 1 & 2 & 3 & 4 & 5 & n/o \\
\hline To enjoy rest and silence & 5 & - & 9 & 39 & 26 & 21 \\
To improve quality of life & 3 & 5 & 28 & 26 & 11 & 27 \\
To make friends and socialize & 11 & 3 & 20 & 34 & 9 & 23 \\
To look for romance & 34 & 17 & 5 & 5 & 5 & 33 \\
To experience something new & 5 & 5 & 13 & 30 & 17 & 30 \\
To escape routines & 12 & 6 & 18 & 22 & 17 & 25 \\
To spend time with my family & 3 & 5 & 9 & 32 & 20 & 31 \\
Others & - & - & - & - & 5 & 95 \\
\hline
\end{tabular}

$\mathrm{N}=141$, Evaluate on a scale from 1 (no importance) to 5 (extremely important), where: * $1=$ no importance,

$2=$ not very important, $3=$ neutral, $4=$ some importance, $5=$ extremely important, $\mathrm{n} / \mathrm{o}-$ no answer.

Source: own study based on the survey.

Nature, a sense of safety, historical sites, quality services and easy transportation connections ( $81 \%$ of the answers in total) are the top five attraction factors for seniors when choosing a destination. Sports, snow, handicrafts, dancing, camping ( $5 \%$ of the answers in total) are the five least attractive factors. Based on the analysis of 31 factors, it can be said that a perfect standard for a senior tourist can be shaped out of the top five attraction factors. Even in the previous answer, safety, easy access, the quality of services, and nature and historical sites are mentioned, so there should be a way for senior tourists in the Warmian and Masurian Voivodeship to be attracted by these factors. The importance of health and medical services are also high.

\section{Conclusions}

The aging of the population has turned attention to the implications for social and economic development. Among them, tourist activity among seniors is noteworthy. ${ }^{20}$ Today's seniors, regardless of strongly rooted stereotypes, are a different social group than in previous decades. ${ }^{21}$ Nowadays, older people are much better educated, live in better conditions, benefit from widely

${ }^{20}$ The information on the tourism activity of seniors and its preferences are also brought up: K. Parzych, Uwarunkowania aktywności turystycznej osób starszych. Studium przypadku słuchaczy Uniwersytetu Trzeciego Wieku w Stupsku, Zeszyty Naukowe Uniwersytetu Szczecińskiego nr 805, Ekonomiczne Problemy Turystyki nr 1 (25), Wydawnictwo Naukowe Uniwersytetu Szczecińskiego, Szczecin 2014, pp. 309-325; J. Zawadka, Preferencje seniorów dotyczace wypoczynku na wsi na terenie Lubelszczyzny i Podlasia, Zeszyty Naukowe Uniwersytetu Szczecińskiego nr 806, Ekonomiczne Problemy Turystyki nr 2 (26), Wydawnictwo Naukowe Uniwersytetu Szczecińskiego, Szczecin 2014, pp. 299-313.

${ }^{21}$ More information about determinants of the tourism consumption of seniors in: M. Walker, Marketing to seniors, 1st Book Library, Bloomington 2004, p. 9; J. Śniadek, Age of Seniors - a Challenge for Tourism and Leisure Industry, "Studies of Physical Culture and Tourism" 2006, No. 13, pp. 103-106; A. Gardner, Travel Is Ageing Gracefully, "Tourism Review Magazine" 2009, p. 44, www.tourism-review.com; I. Patterson, Growing Older. Tourism and Leisure Behavior of Older Adults, CABI Publishing, Wallingford, Cambridge 2006. 
accessible information, and are interested in a professional and socially active lifestyle. This change creates opportunities for the development of many sectors of the economy, ${ }^{22}$ including tourism.

The results of the pilot survey conducted in 2013 as part of the TOURAGE project may provide a basis for further research on a representative sample of people age 55 years and older. The actual test results indicate the significant potential of the Warmian and Masurian Voivodeship in the development of senior tourism and they may be useful in the preparation of offer of travel agencies and social organisations, addressed directly to seniors living in the Warmia and Mazury region. To the respondents, very important factors favouring holidays abroad, preferably in the spring, summer or autumn, are, among others, the possibility to rest in peace and quiet, the cultural values of the place, local traditions and cuisine. It should be emphasized that the Warmia and Mazury region is recognized in numerous scientific studies and strategic documents for the development of tourism in Poland as a region having outstanding qualities in this regard. Its varied landscape with plenty of lakes and forests, numerous architectural monuments and religious buildings all create an incentive for relaxation and sightseeing tours for seniors. The region is also a prominent place in the country in terms of the number of lodgings and accommodations. At the same time, GUS statistics show the region suffers from a major problem with seasonality in tourism: the utilization of beds is the highest in the summer (July and August, on average 45\%) compared to autumn and spring (on average $18-25 \%) .{ }^{23} \mathrm{~A}$ response to this problem could be senior tourism development.

The positive impact of tourist activity on the health and wellbeing of older people is undeniable and confirmed by numerous studies. However, offers for tourists targeted to their specific needs and the opportunities for this market segment in Poland are still relatively modest, despite the fact that seniors are a more numerous and strong consumer group in terms of purchasing potential. The results of the study indicate that the vast majority of seniors in the region of Warmia and Mazury organize their tourist trips on their own, relying on their own experience and by obtaining detailed information about destinations from friends and acquaintances. A big role in this respect could be played by institutions and non-governmental organizations acting on behalf of seniors in society, as well as local governments and entrepreneurs themselves, who unfortunately almost never participate in surveys. The active policy of local authorities in cooperation with entrepreneurs from the tourism sector in the creation of an attractive tourist offer for the elderly, taking into account their physical and mental requirements, can be a source of benefit for both society and the economy as a whole.

22 The answer to these challenge is the conception of „silver economy”, see A. Klimczuk, Srebrna gospodarka $w$ dokumentach strategicznych państwa, in: Zmieniajacy sięświat. Perspektywa demograficzna, społeczna i gospodarcza, Oficyna Wydawnicza SGH, Warszawa 2013. pp. 461-472.

${ }^{23}$ Turystyka w województwie warmińsko-mazurskim w 2013 r., GUS, Warszawa 2014, p. 5. 


\section{References}

Emerytury i renty w 2013 r., GUS, Warszawa 2014.

Europa - najpopularniejszy kierunek turystyczny na świecie - nowe ramy polityczne dla europejskiego sektora turystycznego, KOM (2010) 352, Bruksela 2010.

Evaluation of the Profitability and Economic Impact Generated by the Europe Senior Tourism Programme. Executive summary, Innova Management, Turismo-Ocio-Hotelaría, August 2011, www.europeseniortourism.eu/export/sites/ senior/comun/descargas/evaluationEuropeSeniorTourismProgramme.pdf.

Gardner A., Travel is Ageing Gracefully, in: “Tourism Review Magazine” 2009,

Grzanka-Tykwińska A., Kędziora-Kornatowska K., Znaczenie wybranych form aktywności w życiu osób w podeszłym wieku, „Gerontologia Polska” 2010, t. 18, nr 1. http://epp.eurostat.ec.europa.eu/cache/ITY_PUBLIC/3-08062011BP/EN/3-08062011-BP-EN.PDF.

Klimczuk A., Srebrna gospodarka $w$ dokumentach strategicznych państwa, in: Zmieniajacy się świat. Perspektywa demograficzna, społeczna i gospodarcza, Oficyna Wydawnicza SGH, Warszawa 2013.

Ossowski Z., Taraszkiewicz T., Formella M., Aktywność turystyczna seniorów szansa na rozwój turystyki w Polsce, Ekonomiczne problemy usług nr 82, Zeszyty Naukowe Uniwersytetu Szczecińskiego nr 697, Szczecin 2012.

Parzych K., Uwarunkowania aktywności turystycznej osób starszych. Studium przypadku stuchaczy Uniwersytetu Trzeciego Wieku w Stupsku, Zeszyty Naukowe Uniwersytetu Szczecińskiego nr 805, Ekonomiczne Problemy Turystyki nr 1 (25), Wydawnictwo Naukowe Uniwersytetu Szczecińskiego, Szczecin 2014.

Patterson I., Growing Older. Tourism and Leisure Behavior of Older Adults, CABI Publishing, Wallingford, Cambridge 2006.

Preferencje osób starszych dotyczące wyjazdów turystycznych, Korporacja Badawcza Pretendent, Wrocław 2011.

Rocznik Demograficzny 2010, GUS, Warszawa 2010.

Śniadek J., Age of Seniors - a Challenge for Tourism and Leisure Industry, "Studies of Physical Culture and Tourism" 2006, No. 13.

Śniadek J., Konsumpcja turystyczna polskich seniorów na tle globalnych tendencji w turystyce, "Gerontologia Polska" 2007, t. 15, nr 1-2.

Śniadek J., Zajadacz A., Senior Citizens and Their Leisure Activity: Understanding Leisure Behaviour of Elderly People in Poland, "Studies in Physical Culture and Tourism" 2010, Vol. 17, No. 2.

Sytuacja demograficzna osób starszych i konsekwencje starzenia się ludności Polski w świetle prognozy na lata 20142050, GUS, Warszawa 2014.

Szmigielska B., Bąk A., Hołda M., Seniorzy jako użytkownicy internetu, "Nauka" 2012, nr 2.

Szwarc H., Wolańska T., Łobożewicz T., Rekreacja i turystyka ludzi w starszym wieku. Instytut Wydawniczy Związków Zawodowych, Warszawa 1988.

Turystyka i wypoczynek w gospodarstwach domowych w 2013 r., GUS, Warszawa 2014.

Turystyka w województwie warmińsko-mazurskim w 2013 r., GUS, Warszawa 2014.

Walker M., Marketing to seniors, 1st Book Library, Bloomington 2004.

www.europeseniortourism.eu/pl/index.html.

www.tourage.eu.

Www.tourism-review.com.

Zamłyńska K., Turystyka i rekreacja a promocja zdrowia rodziny, Roczniki Naukowe AWF w Poznaniu nr 54, Poznań 2005.

Zawadka J., Preferencje seniorów dotyczace wypoczynku na wsi na terenie Lubelszczyzny i Podlasia, Zeszyty Naukowe Uniwersytetu Szczecińskiego nr 806, Ekonomiczne Problemy Turystyki nr 2 (26), Wydawnictwo Naukowe Uniwersytetu Szczecińskiego, Szczecin 2014.

Zielińska-Szczepkowska J., Źróbek-Różańska A., Aktywność władz samorządowych w obliczu zmian demograficznych kształtujacych sektor turystyczny, przykład województwa warmińsko-mazurskiego, Studia i Prace Wydziału Nauk Ekonomicznych i Zarządzania nr 37, Zeszyty Naukowe Uniwersytetu Szczecińskiego nr 826, Wydawnictwo Naukowe Uniwersytetu Szczecińskiego, Szczecin 2014. 


\title{
AKTYWNOŚĆ TURYSTYCZNA OSÓB STARSZYCH \\ - PRZYKŁAD WOJEWÓDZTWA WARMIŃSKO-MAZURSKIEGO
}

\begin{abstract}
SŁOWA KLUCZOWE | starzenie się społeczeństwa, aktywność turystyczna, preferencje turystyczne seniorów
\begin{tabular}{l|l} 
STRESZCZENIE & W niniejszym artykule zaprezentowano wyniki pilotażowych badań ankietowych prze-
\end{tabular} prowadzonych w okresie wakacyjnym 2013 r. na próbie 141 osób w wieku 55 lat i więcej, zamieszkujących województwo warmińsko-mazurskie. Celem badań zrealizowanych w ramach projektu „TOURAGE - rozwój turystyki osób starszych w regionach peryferyjnych", było nakreślenie sylwetki przeciętnego seniora - turysty z regionu Warmii i Mazur oraz określenie jego preferencji turystycznych. Omówione zostały motywy podejmowania przez respondentów podróży, a także charakter tych wyjazdów. Rozważania poszerzono o zagadnienia aktywności turystycznej osób starszych.
\end{abstract}

